\title{
STEM Education Implementation in Indonesia: A Scoping Review
}

Submitted 30 May 2021, Revised 21 June 2021, Accepted 29 June 2021

\author{
Ratna Farwati ${ }^{1 *}$, Kartika Metafisika ${ }^{2}$, Indah Sari ${ }^{3}$, Debora Suryani Sitinjak ${ }^{4}$, Dian Farkhatus Solikha ${ }^{5}$, \\ Solfarina Solfarina ${ }^{3}$ \\ ${ }^{1}$ Department of Chemistry Education, Faculty of Tarbiya and Teaching Sciences, \\ Universitas Islam Negeri Raden Fatah, Palembang, Indonesia \\ ${ }^{2}$ Department of Primary School Teacher Education, Faculty of Tarbiya, \\ Sekolah Tinggi Agama Islam Taruna, Surabaya, Indonesia \\ ${ }^{3}$ Department of Chemistry Education, Faculty of Teacher Training and Education, \\ Universitas Sultan Ageng Tirtayasa, Serang, Indonesia \\ ${ }^{4}$ Department of Chemistry Education, Faculty of Educational Sciences, \\ Universitas Pelita Harapan, Tangerang, Indonesia \\ ${ }^{5}$ Department of Chemical Engineering, Akademi Minyak dan Gas Balongan, Indramayu, Indonesia \\ Corresponding author: *ratna.farwati@gmail.com
}

\begin{abstract}
In Indonesia, STEM education has been implemented in the learning process since 2014. The number of researches on the implementation of STEM education are increasing from year to year. Therefore, this research was conducted to map the all articles published online with the theme of STEM education implementation in Indonesia. The scoping review was carried out following the framework from Arksey \& O'Malley (2005), with the following steps: (1) formulating research questions, (2) exploring research results on Google Scholar database from 2015-2020 with the keyword "implementation" + "STEM education" + "Indonesia", (3) sorting the collected articles with predetermined criteria and selecting them according to the PRISMA model, (4) discussion, and (5) conclusion. Found 597 articles that match to these keywords and 154 articles that meet the criteria as research data. The results showed that the STEM education is implemented as a learning strategy and approach, integrated with other learning models, used as a learning assessment, and developed into teaching materials, modules, and learning media. Additionally, teachers implement STEM to improve entrepreneurship skills, learning motivation, and various $21^{\text {st }}$-century skills in their students. Furthermore, research on STEM has been conducted in 19 provinces in Indonesia, which are dominated by West Java and East Java provinces. Beside that, the STEM education has been studied at all levels of education and high school is the most widely used research subject and STEM education has grown in small units and has proven to be capable of developing many student skills. The implementation of STEM education can be a trigger for renewal in the world of education.
\end{abstract}

Keywords: scoping review, STEM education, Indonesia

\section{INTRODUCTION}

The issue of science, technology, engineering, and mathematics (STEM) education has developed very rapidly in all countries. The comprehensive integration of the four disciplines provides great potential to improve the quality of learning. STEM can encourage students to be skilled in designing, developing, and utilizing technology, as well as applying integrated knowledge to solve problems (Kapila, 2014). Therefore, STEM education is very interesting for researchers and teachers.

Teachers play an important role in the implementation of STEM (McDonald, 2016). In science learning, STEM is an alternative learning model that is able to build a capable and skilled 21st century generation (Permanasari, 2016) and also meet the challenges of industry 4.0. In addition, teachers can use STEM education as a learning strategy, learning approach, 
learning method, assessment, learning media, teaching materials, and textbooks (Farwati et al., 2021).

In Indonesia, STEM Education has been started to be researched in 2014. This information was obtained from the Google Scholar database. The first publication found was the thesis of a chemical education student in Aceh, Nanggroe Aceh Darussalam, Indonesia. In 2014 there was only one publication in the form of the thesis. However, as time goes on, more and more reviews about STEM are being netted by researchers in Indonesia. There are 3,680 articles on Google Scholar with the keyword "STEM education" Indonesia and 597 articles with the keyword implementation of "STEM education" Indonesia for 2015-2020. Therefore, it is necessary to map out research on the implementation of STEM education in Indonesia.

Ananda \& Salamah (2021) have mapped national articles on the effect of STEM implementation on students' critical thinking in Indonesia. In addition, a review of the effect size of the use of STEM-based teaching materials in science (Izzah et al., 2021) and learning ecology (Santosa et al., 2021) has been reported. However, previous studies only focus on examining one skill and one teaching media for the elementary-high school level, not covering all levels of education units and all STEM research themes that have been implemented in Indonesia.

Based on this background, the purpose of this study is to map all research themes related to the implementation of STEM education in Indonesia in the science field and the scientific clumps of science from 2015-2020, starting from elementary school to tertiary education levels. In addition, this study also conducted data collection on research locations to be able to see the distribution of research on STEM implementation throughout Indonesia. The results of this study are expected to describe the development of research on STEM implementation from year to year, the education level of the participants involved, the (province) research location, and all research themes on STEM education in Indonesia that have been carried out. This information can be used as consideration for making policies related to STEM in Indonesia. In addition, the report from this study can also show the extent of efforts to improve the quality of education in Indonesia with STEM education.

\section{METHOD}

This study is a scoping review using Arksey and O'Malley's five-stage framework, including identifying research questions, identifying relevant studies, study selection, charting the data, summarizing and reporting the results were utilized in this review (Arksey \& O’Malley, 2005). The stages of identifying research questions, identifying relevant studies, and 
study selection will be presented in the method section, but the stages of charting the data, summarizing, and reporting the results will be presented in the result and discussion section.

\section{Identifying Research Questions}

This review was focused on exploration about three aspects, including research theme, research participants, and location (province in Indonesia) STEM Education was implemented. The following research questions are submitted to guide the research to capture literature that is in line with the focus of this study:

1. What are the research themes of STEM Education implemented in Indonesia?

2. Who are the research participants involved in research on the implementation of STEM Education in Indonesia?

3. In which provinces in Indonesia is STEM Education research conducted?

\section{Identifying Relevant Studies}

The second step is identifying relevant studies. Keyword "implementation" + "STEM Education" + "Indonesia" is selected to capture literature regarding the implementation of STEM Education in Indonesia. The reason for selecting 'STEM Education + Indonesia STEM Education + Indonesia' as a search term was to reach out to as many relevant studies as possible. Afterward, inclusion and exclusion criteria were developed to get insights about the aspect that can be included to summarize the selected studies. Table 1 shows the inclusion and exclusion criteria.

Table 1. Inclusion and exclusion criteria

\begin{tabular}{|c|c|c|}
\hline Criteria & Inclusion & Exclusion \\
\hline Time Period & $2015-2020$ & Outside these time period \\
\hline Focus of Study & $\begin{array}{l}\text { a. Quantitative and development research } \\
\text { b. Implemented on science education, } \\
\text { chemistry education, biology } \\
\text { education, and physics education } \\
\text { c. Study location in Indonesia } \\
\text { d. Published in journals and conference } \\
\text { proceedings }\end{array}$ & $\begin{array}{l}\text { a. Qualitative research } \\
\text { b. Implemented on outside } \\
\text { science education, } \\
\text { chemistry education, } \\
\text { biology education, and } \\
\text { physics education } \\
\text { c. Study location in other } \\
\text { countries }\end{array}$ \\
\hline Participant & $\begin{array}{l}\text { Students in formal education: Elementary } \\
\text { School, Junior High School, Senior High } \\
\text { School, Vocational School, and } \\
\text { undergraduate School focus on science } \\
\text { education. }\end{array}$ & $\begin{array}{l}\text { Student in non-formal } \\
\text { education or informal } \\
\text { participant }\end{array}$ \\
\hline
\end{tabular}

\section{Study Selection}

The article selection process on this study followed the PRISMA model in the form of a four-phase flow diagram, including identification, screening, eligibility, and inclusion (Moher, et al., 2009). The stages of the article selection process can be seen in Figure 1. 


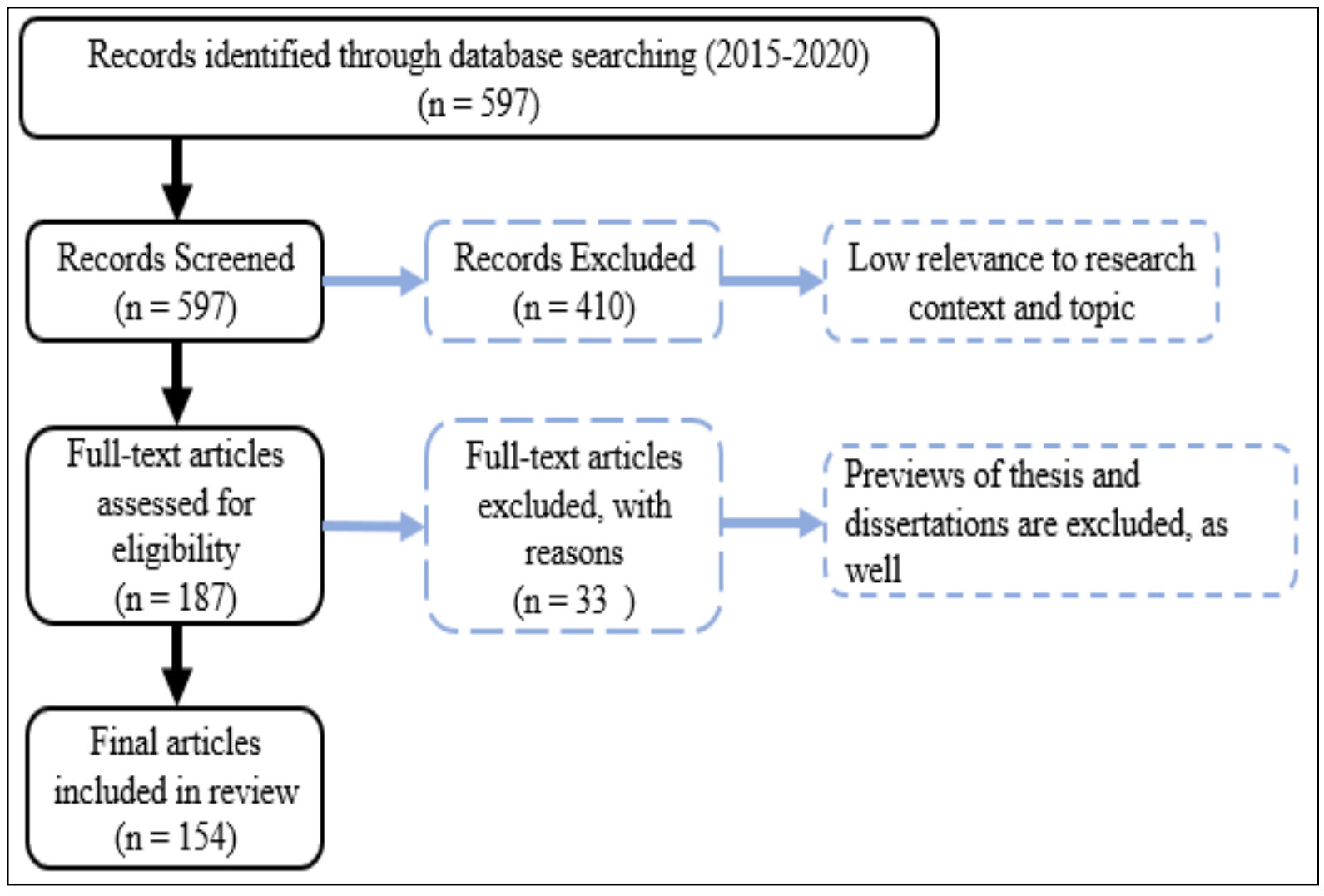

Figure 1. PRISMA flow diagram for article selection

Figure 1 shows the fact that most of the articles were irrelevant with inclusion criteria. Studies about the implementation of STEM Education for another subject are excluded, i.e. career interest in the field of STEM, didactic reduction, systematic literature review (SLR), and teacher training. Moreover, the preview of thesis and dissertations are also excluded.

\section{RESULTS AND DISCUSSION}

\section{Charting the Data}

The next step in this scoping review was charting the selected articles. The final articles included in review as many as 154 articles related to implementation of STEM Education in Indonesia. After each study is perceived to be included in the inclusion criteria, summaries are developed for each article with several variables, including the author(s), year, the theme of research, participant, and location. Table 2 shows descriptive information of reviewed articles.

Table 2. Descriptive Information Related to the Reviewed Articles.

$\begin{array}{ccc}\begin{array}{c}\text { Research } \\ \text { Theme }\end{array} & \text { Educational Level } & \text { Research Location }\end{array}$

\begin{tabular}{llll}
\hline Assessment & Elementary School & West Java & $\begin{array}{l}\text { Hamdu et al. (2019), Nurlenasari et } \\
\text { al. (2019), Kurniasih et al. (2020), }\end{array}$ \\
& & & $\begin{array}{l}\text { Rahmat et al. (2020), Syadiah \& } \\
\text { Hamdu (2020) }\end{array}$ \\
& & & Suprapto (2016) \\
& Junior High School & East Java & Supahar \& Nurcahyanto (2015) \\
\hline Senior High School & DI Yogyakarta & \\
\hline
\end{tabular}




\begin{tabular}{|c|c|c|c|}
\hline $\begin{array}{l}\text { Research } \\
\text { Theme }\end{array}$ & Educational Level & Research Location & Authors \\
\hline \multirow{17}{*}{$\begin{array}{l}\text { teaching } \\
\text { materials }\end{array}$} & & & Putri \& Istiyono (2017) \\
\hline & Vocational High & DKI Jakarta & Candraningrum \& Dhewy (2016) \\
\hline & School & West Java & Septiani \& Rustaman (2017) \\
\hline & \multirow[t]{2}{*}{ Undergraduate } & East Java & Mayasari et al. (2016) \\
\hline & & West Java & Nanang et al. (2018) \\
\hline & \multirow{4}{*}{ Elementary School } & Bangka Belitung & Yuanita \& Kurnia (2019) \\
\hline & & DI Yogyakarta & Erviana \& Asmara (2019) \\
\hline & & West Java & Hamdu \& Rostiana (2020) \\
\hline & & & Nisa \& Nugroho (2020) \\
\hline & \multirow[t]{2}{*}{ Junior High School } & West Java & Rusyati et al. (2019) \\
\hline & & East Java & Sukmagati et al. (2019) \\
\hline & \multirow[t]{5}{*}{ Senior High School } & Central Java & Pangesti et al. (2017) \\
\hline & & East Java & Utomo et al. (2018) \\
\hline & & & Ningtyas et al. (2019) \\
\hline & & Riau & Azura \& Octarya (2020) \\
\hline & & DKI Jakarta & Supriyati et al. (2020) \\
\hline & $\begin{array}{l}\text { Undergraduate } \\
\text { School }\end{array}$ & South Sumatra & $\begin{array}{l}\text { Negara et al. (2017), Rachmawati et } \\
\text { al. (2017), Riandry et al. (2017) }\end{array}$ \\
\hline \multirow[t]{5}{*}{ worksheets } & \multirow[t]{2}{*}{ Elementary School } & West Java & Fatimah et al. (2019) \\
\hline & & $\begin{array}{l}\text { West Nusa } \\
\text { Tenggara }\end{array}$ & Haifaturrahmah et al. (2020) \\
\hline & \multirow{2}{*}{ Junior High School } & East Java & Fitriyah \& Wardana (2019) \\
\hline & & Central Java & Sukmagati et al. (2020) \\
\hline & Senior High School & $\begin{array}{l}\text { Nanggroe Aceh } \\
\text { Darussalam }\end{array}$ & Rahmiza et al. (2015) \\
\hline \multirow{16}{*}{$\begin{array}{l}\text { Learning } \\
\text { Media }\end{array}$} & \multirow[t]{5}{*}{ Elementary School } & DI Yogyakarta & Erviana (2019) \\
\hline & & $\begin{array}{l}\text { Nanggroe Aceh } \\
\text { Darussalam }\end{array}$ & Setiawati et al. (2020) \\
\hline & & Lampung & Saputra et al. (2020) \\
\hline & & West Java & $\begin{array}{l}\text { Firdaus \& Hamdu (2020) } \\
\text { Sakinah et al. (2020) }\end{array}$ \\
\hline & & DI Yogyakarta & Maula \& Fatmawati (2020) \\
\hline & \multirow{3}{*}{ Junior High School } & West Java & Afriana et al. (2016) \\
\hline & & Lampung & Sudarsono et al. (2019) \\
\hline & & Central Java & Sari \& Apriyantika (2020) \\
\hline & \multirow[t]{4}{*}{ Senior High School } & Central Java & Santoso \& Mosik (2019) \\
\hline & & East Java & $\begin{array}{l}\text { Rokhim et al. (2020), Widarti et al. } \\
(2020)\end{array}$ \\
\hline & & Lampung & Iqbal et al. (2019) \\
\hline & & East Java & Susanti et al. (2018) \\
\hline & \multirow{4}{*}{$\begin{array}{l}\text { Undergraduate } \\
\text { School }\end{array}$} & DKI Jakarta & Dewati et al. (2019) \\
\hline & & Central Java & Hidayati et al. (2019) \\
\hline & & East Nusa & Wahyu et al. (2020) \\
\hline & & Tenggara & \\
\hline
\end{tabular}




\begin{tabular}{|c|c|c|c|}
\hline $\begin{array}{l}\text { Research } \\
\text { Theme }\end{array}$ & Educational Level & Research Location & Authors \\
\hline \multirow[t]{7}{*}{ module } & Junior High School & East Java & $\begin{array}{l}\text { Basuki et al. (2018), Alfika et al. } \\
\text { (2019), Almuharomah et al. (2019), } \\
\text { Safitri et al. (2019), Septaria et al. } \\
\text { (2020) }\end{array}$ \\
\hline & \multirow{3}{*}{ Senior High School } & East Java & Sampurno et al. (2015) \\
\hline & & Riau & Syahirah et al. (2020) \\
\hline & & South Sumatra & Oktaviani et al. (2020) \\
\hline & \multirow{3}{*}{$\begin{array}{l}\text { Undergraduate } \\
\text { School }\end{array}$} & Nanggroe Aceh & Sakdiah et al. (2020) \\
\hline & & Darussalam & \\
\hline & & South Sumatra & Zuriyatina et al. (2020) \\
\hline \multirow{23}{*}{$\begin{array}{l}\text { Model/ } \\
\text { Strategy/ } \\
\text { Approach }\end{array}$} & \multirow[t]{7}{*}{ Elementary School } & Nanggroe Aceh & Siregar et al. (2019) \\
\hline & & Darussalam & \\
\hline & & West Java & Firdaus \& Rahayu (2019) \\
\hline & & Central Java & $\begin{array}{l}\text { Gandi et al. (2019), Mufidah et al. } \\
\text { (2019), Septine et al. (2019) }\end{array}$ \\
\hline & & Lampung & Abdurrahman et al. (2019) \\
\hline & & Central Java & $\begin{array}{l}\text { Akhmad et al. (2020), Baihaqi et al. } \\
\text { (2020), Dywan \& Airlanda (2020), } \\
\text { Ridlo et al. (2020), Twiningsih } \\
\text { (2020) }\end{array}$ \\
\hline & & West Borneo & Priyani \& Nawawi (2020) \\
\hline & \multirow[t]{12}{*}{ Junior High School } & West Java & $\begin{array}{l}\text { Sumarwa et al. (2015), Ismail et al. } \\
\text { (2016), Khaeriningtyas et al. (2016), } \\
\text { Agustina et al. (2017), Fitriani et al. } \\
\text { (2017), Tati et al. (2017), Hani \&, } \\
\text { Suwarma (2018), Haryanti \& } \\
\text { Suwarma (2018), Liliawati et al. } \\
\text { (2018), Nuraziza \& Suwarma (2018) }\end{array}$ \\
\hline & & East Java & Sugiarti et al. (2018) \\
\hline & & Central Java & Lestari et al. (2018) \\
\hline & & West Java & $\begin{array}{l}\text { Mu'minah \& Aripin (2019), } \\
\text { Sulistiowati et al. (2019) }\end{array}$ \\
\hline & & $\begin{array}{l}\text { West Nusa } \\
\text { Tenggara }\end{array}$ & Hera \& Lamanepa (2019) \\
\hline & & East Java & Prismasari et al. (2019) \\
\hline & & Central Java & Lathif et al. (2019) \\
\hline & & Nanggroe Aceh & Julia et al. (2020) \\
\hline & & Darussalam & \\
\hline & & DKI Jakarta & Haryati et al. (2020) \\
\hline & & West Java & Heryanti (2020), Rustaman (2020) \\
\hline & & East Java & Indriyawanti et al. (2020) \\
\hline & \multirow[t]{4}{*}{ Senior High School } & $\begin{array}{l}\text { Nanggroe Aceh } \\
\text { Darussalam }\end{array}$ & Adlim et al. (2015) \\
\hline & & East Java & Ariesta et al. (2015) \\
\hline & & West Java & $\begin{array}{l}\text { Kaniawati \& Suryadi (2016), Dewi et } \\
\text { al. (2018) }\end{array}$ \\
\hline & & East Java & Rivai et al. (2018) \\
\hline
\end{tabular}




\begin{tabular}{|c|c|c|c|}
\hline \multirow[t]{38}{*}{$\begin{array}{l}\text { Research } \\
\text { Theme }\end{array}$} & Educational Level & Research Location & Authors \\
\hline & & DI Yogyakarta & Wisudawati (2018) \\
\hline & & Bali & Wibowo (2018) \\
\hline & & Nanggroe Aceh & Munandar et al. (2019) \\
\hline & & Darussalam & \\
\hline & & Sumatra Barat & Gevi (2019) \\
\hline & & Lampung & Rosidin et al. (2019) \\
\hline & & Lampung & Sagala et al. (2019) \\
\hline & & DKI Jakarta & Rahmawati et al. (2019) \\
\hline & & West Java & $\begin{array}{l}\text { Aninda et al. (2019), Cholisoh } \\
\text { (2019), Fikri et al. (2019), Hanif et al. } \\
\text { (2019) }\end{array}$ \\
\hline & & Central Java & $\begin{array}{l}\text { Aryani et al. (2019), Yulianti et al. } \\
(2019)\end{array}$ \\
\hline & & DI Yogyakarta & Triastuti (2019) \\
\hline & & East Java & $\begin{array}{l}\text { Ananda \& Dasna (2019), Hudha et al. } \\
\text { (2019), Maulidi et al. (2019), } \\
\text { Rizkihati et al. (2019), Sumardiana et } \\
\text { al. (2019), Sutoyo et al. (2019) }\end{array}$ \\
\hline & & $\begin{array}{l}\text { West Nusa } \\
\text { Tenggara }\end{array}$ & $\begin{array}{l}\text { Ardianti et al. (2019), Musyasarah et } \\
\text { al. (2019), Pranita et al. (2019) }\end{array}$ \\
\hline & & South Borneo & Rahman et al. (2019) \\
\hline & & Lampung & Syafei et al. (2020) \\
\hline & & East Java & Darmawan (2020) \\
\hline & & East Java & $\begin{array}{l}\text { Hasbullah et al. (2020), Khotimah et } \\
\text { al. (2020), Lukitawanti et al. (2020), } \\
\text { Paramita et al. (2020), Putri et al. } \\
\text { (2020)Roja et al. (2020) }\end{array}$ \\
\hline & & Central Java & $\begin{array}{l}\text { Ariyatun \& Oktavianelis (2020) } \\
\text { Nurfadilah \& Siswanto (2020) }\end{array}$ \\
\hline & & Gorontalo & Utina (2020) \\
\hline & & Lampung & Saputri et al. (2020) \\
\hline & & East Java & Agustin (2020) \\
\hline & & & Devi et al. (2020) \\
\hline & & West Nusa & Ardianti et al. (2020) \\
\hline & & Tenggara & \\
\hline & Vocational High & DI Yogyakarta & Safitri \& Priyambodo (2016) \\
\hline & School & West Java & Apriyani et al. (2019) \\
\hline & & Bali & Sudiatmika (2020) \\
\hline & Undergraduate & Nanggroe Aceh & Setiawaty et al. (2018) \\
\hline & School & Darussalam & \\
\hline & & Central Java & Wijayanti \& Fajriyah (2018) \\
\hline & & & Farwati et al. (2018) \\
\hline & & South Sumatra & Winda et al. (2019) \\
\hline & & West Java & Ardianto et al. (2019) \\
\hline & & & Agustina et al. (2019) \\
\hline & & South Sulawesi & Anita et al. (2019) \\
\hline & & Gorontalo & Sunardi \& Hasanuddin (2019) \\
\hline & & Papua & Yusuf \& Widyaningsih (2019) \\
\hline
\end{tabular}




\begin{tabular}{clll}
\hline $\begin{array}{c}\text { Research } \\
\text { Theme }\end{array}$ & Educational Level & Research Location & \multicolumn{1}{c}{ Authors } \\
\hline \multirow{5}{*}{ Lesson Plan } & Nanggroe Aceh & Sari et al. (2020) \\
& & Darussalam & Nurkanti et al. (2020) \\
& & West Java & Meishanti (2020) \\
& & East Java & Pratama et al. (2020) \\
& & DI Yogyakarta & Pujiati (2020) \\
& DKI Jakarta & Widiyanti \& Mizan (2020) \\
\hline
\end{tabular}

\section{Summarizing and Reporting Findings}

The last step of Arksey and O'Malley's five-stage framework is summarizing and reporting findings. What is meant by the implementation of STEM education in this study is the result of applying STEM education in learning. The application of STEM education can be in strategies, approaches, models, or learning methods. In addition, the application of STEM education can also be used as teaching materials, modules, student worksheets, learning media, and learning assessments (Farwati et al., 2021). Therefore, the implementation of STEM education is synonymous with quantitative research and development.

In 2014 only one publication was found on the implementation of STEM education in Indonesia. The publication is in the form of a repository of thesis for Chemistry education students in Aceh, Nanggroe Aceh Darussalam. No other articles related to STEM education were found that were published on Google Scholar, and this study took data on Google Scholar for the 2015-2020 period.

From 2015 the number of studies on STEM implementation in education continued to increase, until there was a significant increase in 2019. The number of studies on the implementation of STEM education in 2019 jumped 2.5 times from 2018. This data shows the enthusiasm of teachers and researchers related to STEM education. Nevertheless, the overall number of studies on the implementation of STEM education in Indonesia is still quite apprehensive.

Netted 154 articles in the last six years researching the implementation of STEM education. Thus, only about 26 studies per year are conducted on STEM implementation. This number is relatively minimal because it is compared to the number of teachers and researchers in the science field and the many science clusters in Indonesia. These findings should be taken into consideration for: (1) Increasing the socialization of STEM education to students and teachers of Science, Chemistry, Biology, and Physics; (2) Encouraging and facilitating students and teachers of science and science clusters to conduct research related to STEM 
implementation; (3) Establish a discussion forum with structured activities related to STEM education in every province in Indonesia. This way is expected to increase the interest of researchers in the implementation of STEM education.

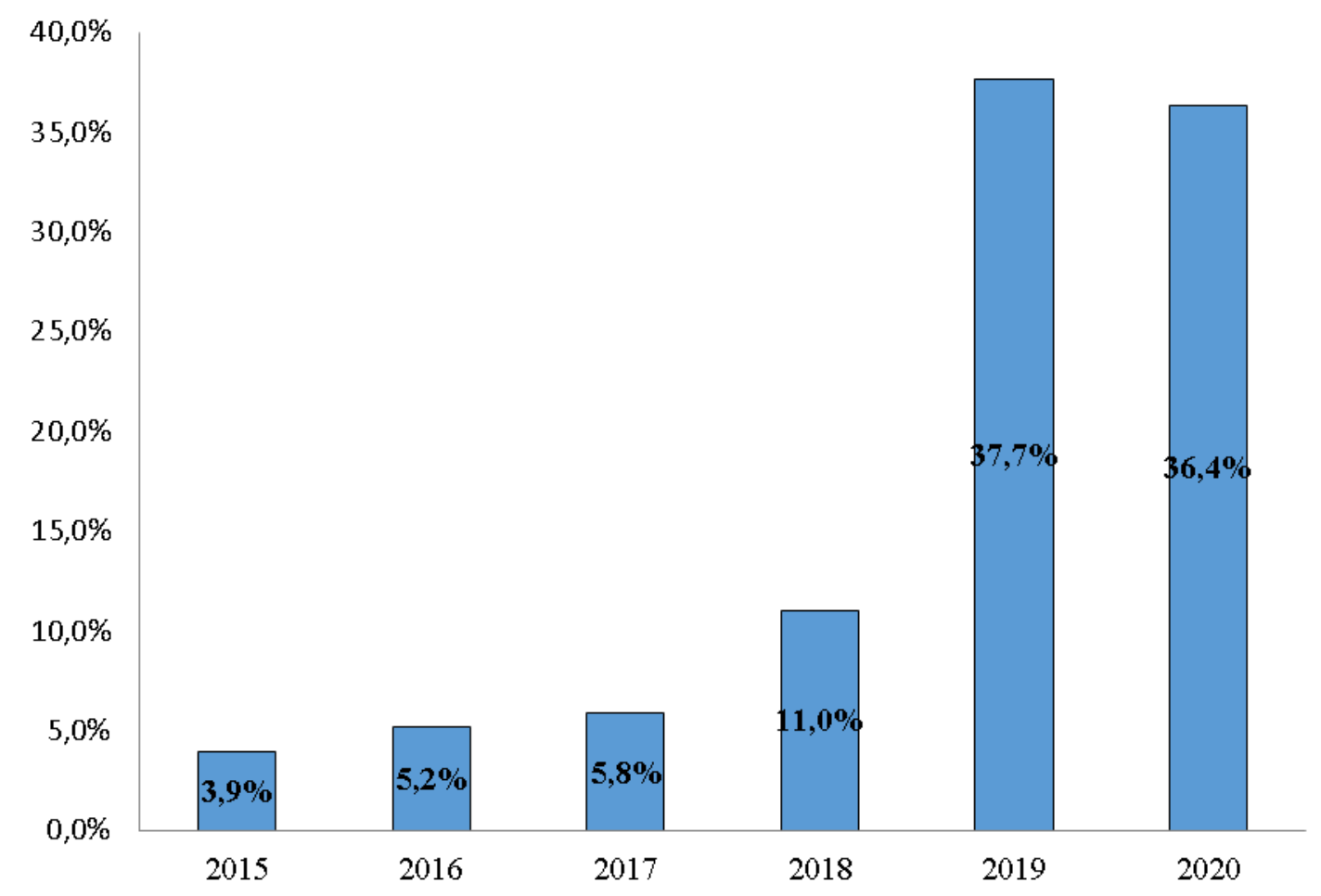

Figure 2. Trends in STEM Education Research in Indonesia 2015-2020

The implementation of STEM education in 2019 and 2020 accounted for $74.1 \%$ of the overall data from 2015 to 2020, as shown in Figure 2. STEM research trends experienced a dramatic increase in 2019 and 2020, but the number of studies in 2020 less (1.3\%) compared to 2019. The decrease in the number of studies is thought to be influenced by the Covid-19 pandemic. This condition has an impact on the education process in various countries in the world, including in Indonesia (Abidah et al., 2020; Areba, 2020; Franchi, 2020; Iyer et al., 2020; Nambiar, 2020; Popyk, 2020; Putri et al., 2020; Rizun \& Strzelecki, 2020; Sari et al.). The government enforces a policy of studying from home during the Covid-19 pandemic for high school levels. Likewise for higher education levels are based on the circular of the Ministry of Research, Technology and Higher Education No. 1 of 2020, which urges universities to conduct learning remotely or online. This policy, of course, also has an impact on research on the implementation of STEM education because STEM-based learning is commonly done through face-to-face learning in schools. Meanwhile, during the Covid-19 pandemic, learning is carried out online. Online learning is carried out using zoom, jitzi, google meet, Webex applications, and the teacher makes short explanatory videos that can be shared 
via WhatsApp and YouTube media, where the video recordings can be used repeatedly (Pujiasih, 2020). In addition, Edmodo, Moodle, email, study houses, and Schoology applications can also be used (Sari, 2020).

The decline in STEM research trends in 2020 indicates the need to revive STEM research. Various aspects of STEM skills need to be developed in students in order to produce quality future generations and be able to compete globally. STEM research in the pandemic era can be integrated with online learning through the use of augmented reality (AR) and virtual reality (VR) technology. AR can be applied in distance learning (Ahied et al., 2020; Altinpulluk et al., 2020; Faregh \& Sisi, 2020) as well as VR (Fauville et al., 2021; Georgieva-Tsaneva \& Serbezova, 2020; Harfouche \& Nakhle, 2020; McFaul \& FitzGerald, 2020). Several studies have also suggested that AR and VR technology can be used in STEM learning (Christopoulos et al., 2020; Nordin et al., 2020; Petrov \& Atanasova, 2020; Yildrim et al., 2020; Wahyu et al., 2020). Thus, it is necessary to train AR and VR skills for both teachers and prospective teachers so that they can continue to carry out STEM learning during the COVID-19 pandemic in order to create quality education. Education is the most important basis to face the era of society 5.0, which becomes a serious challenge if human resources are not well prepared and mature for the golden generation as the successor of the nation's progress (Pujiasih, 2020).

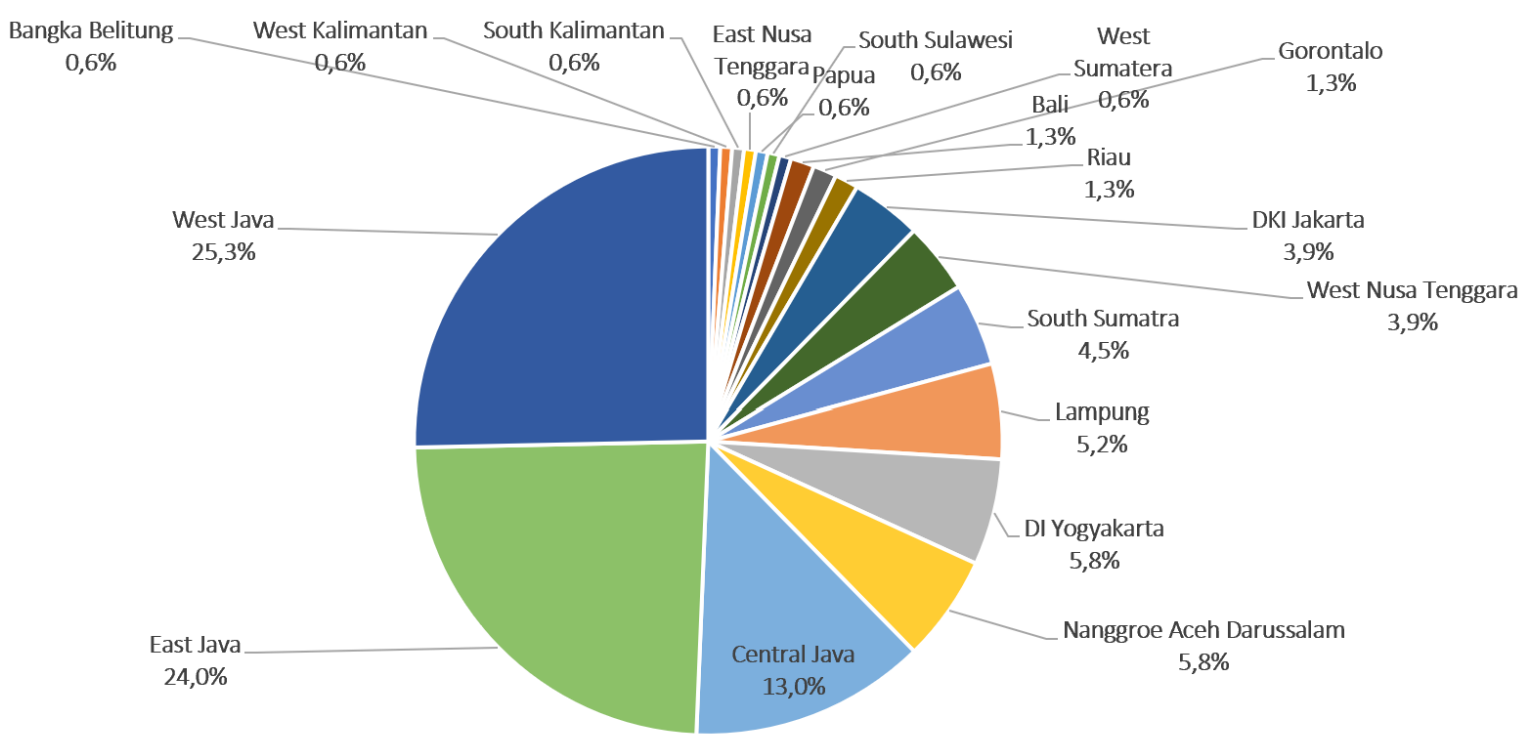

Figure 3. Distribution of STEM Implementation Research Locations in Learning

The distribution of STEM research is still concentrated in only two provinces: West Java and East Java, reaching 49.3\% as shown in Figure 3. There are 44\% of provinces that are not recorded as implementing STEM education in learning. This data shows that there is no equal distribution of information about STEM education, and there is no uniformity in the spirit 
of reform in education from teachers in all provinces in Indonesia. Thus, more effort is needed for provinces that are not familiar with STEM education.

Efforts that can be made to disseminate information about STEM are to conduct socialization and mentoring about STEM, as has been done by lecturers in Bali who carried out socialization through community partnership programs about making learning implementation plans by implementing STEM. These activities are poured into writing in the form of a journal. The benefit of these activities is that teachers are able to make learning implementation plans by implementing STEM (Sukendra et al., 2020). Thus, socialization and assistance related to STEM have the potential to be carried out in Indonesia. In addition, direction from universities is also needed for their students to conduct research on STEM education in other areas so that they are not concentrated in Java. Universities can also do community service in the form of training activities for teachers outside the island of Java for the purpose of this equity. Another alternative that can be done is to raise the issue of local wisdom to be integrated into STEM education (Almuharomah et al., 2019; Prasadi et al., 2020; Priyani \& Nawawi, 2020). Indonesia has cultural diversity. Each region in Indonesia has its own cultural characteristics. This uniqueness becomes the potential in bringing up STEM education research ideas that are integrated with local wisdom issues for each region. It is hoped that the distribution of STEM education research in Indonesia is more evenly distributed.

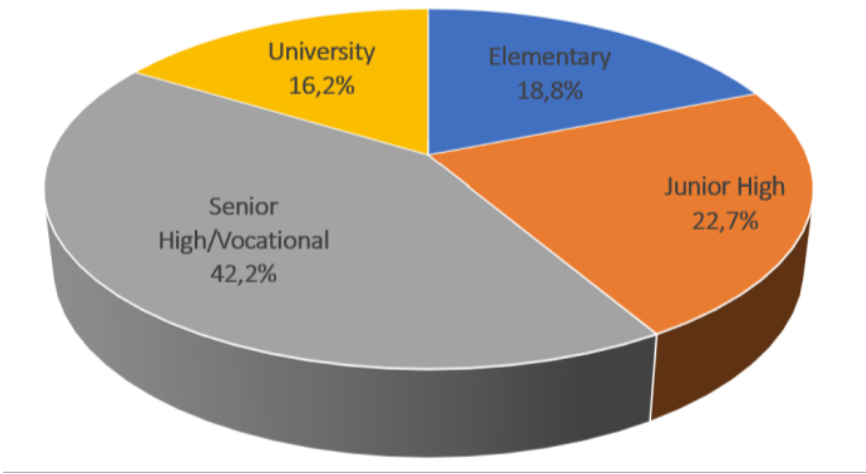

Figure 4. Implementation of STEM Learning Research Based on Participant Education Unit Level.

Figure 4 shows that research on STEM implementation at the high school level dominates with a percentage of $42.2 \%$ compared to other education unit levels. This dominant number indicates a need to socialize more massive STEM learning at other levels of education. There are universities with science study programs and/or science clusters in every province in Indonesia. In addition, there are also teachers who teach science and science clusters at the 
elementary, junior high, and high school/vocational schools throughout Indonesia. Socialization about STEM education can be done through seminars organized by student associations at the university level by involving students and teachers in the local province. The more people who do research related to STEM, the more new ideas related to STEM itself will appear. This will trigger more varied STEM research themes at the education unit level. In addition, support from the government is also needed. However, there have been many STEM training carried out by the Ministry of Education and Culture for teachers and launched a pilot school program that implements STEM learning (Aceh, 2021; Atik, 2018; Ministry of Education and Culture, 2020; PPPPTK \& PLB, 2020). However, the Ministry of Education and Culture is also expected to create a collaborative program with university associations that have education study programs to map the direction of STEM education in Indonesia, given that the goal of STEM education is to instill $21^{\text {st }}$-century skills so that it is important to do it at all levels of education.

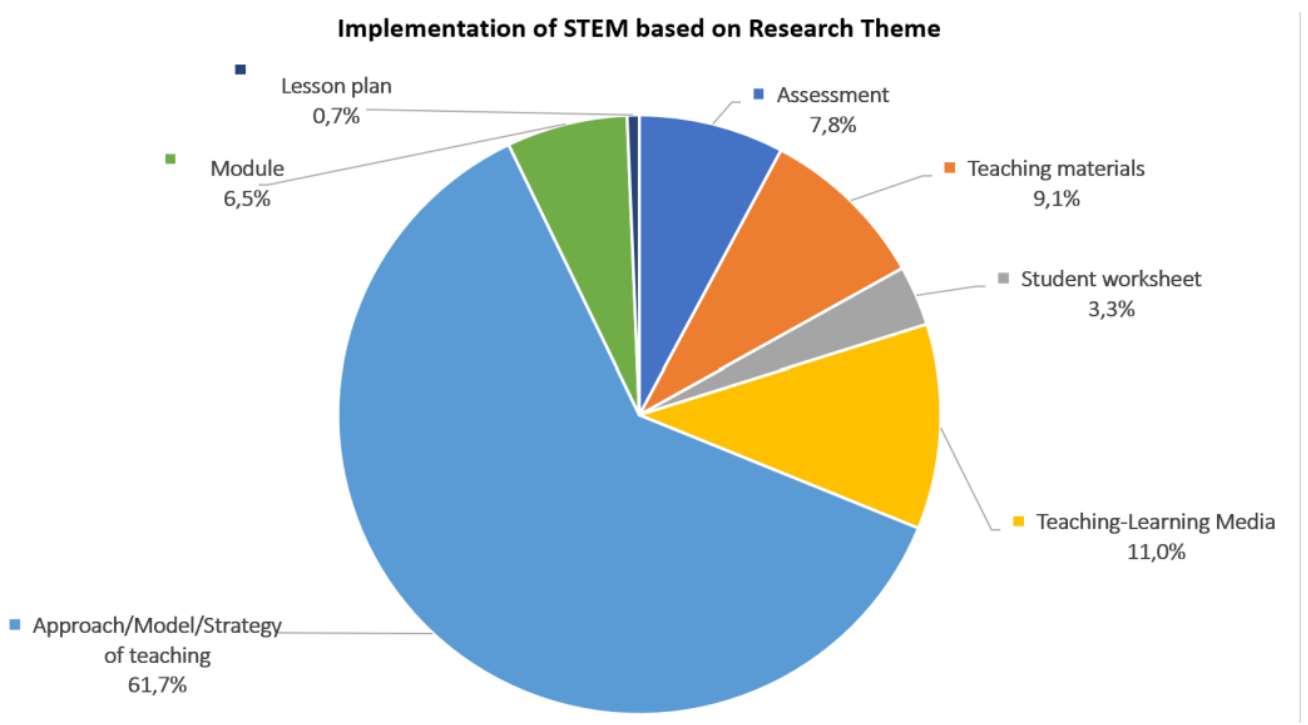

Figure 5. Implementation of STEM Learning Based on Research Theme

In 2015-2020 research on STEM-based learning strategies/approaches/models is very dominantly carried out by researchers in Indonesia, as shown in Figure 5. The research themes are found every year and starting in 2019. This research theme has been carried out at all levels of education. Whereas in previous years, the research theme only involved students at the junior high and high school levels. Overall, the theme of this study mostly involved students at the high school level as participants. 
There are 5 other research themes that can be mapped from the publication of STEM implementation in Indonesia in 2015-2020, as presented in Figure 5. These various research themes were carried out to hone a series of skills needed by students, such as literacy (Sampurno, 2015; Afriana et al., 2016; Tati et al., 2017; Farwati et al., 2018; Anita et al., 2019), entrepreneurial ability (Adlim et al., 2015), and so on. Broadly speaking, the implementation of STEM in learning can improve the $21^{\text {st }}$-century skills of students (Permanasari, 2016; Farwati et al., 2021). These skills are needed by students to be able to play an active role while in the community. Therefore, STEM education should be used by all teachers, especially from the elementary school level. However, in the last six years, the implementation of STEM has involved the most participants at the high school level, reaching $42 \%$. Thus, strong stimulation is needed so that other education unit-level teachers are interested in innovating by implementing STEM in classroom learning.

\section{CONCLUSION}

The peak of the increase in the number of research on the implementation of STEM education in Indonesia occurred in 2019. However, the Covid-19 pandemic resulted in a decrease in the number of STEM implementations in 2020, but not significantly. In 2015-2020, the implementation of STEM education was most widely used as a strategy/approach/learning model. The most frequently involved participants were high school students. Researchers from the provinces of West Java and East Java are the most active in conducting research on STEM implementation in the last six years. STEM-based learning has the potential to improve students' $21^{\text {st }}$-century skills. Therefore, the implementation of STEM education needs to be carried out evenly at all levels of education units and in all provinces in Indonesia. Stimulation and assistance to students and teachers are needed so that STEM education can touch all lines. Activities such as STEM-related competitions, STEM-based product exhibitions, and special research funds related to STEM, and training on the use of AR and VR for STEM-based learning during a pandemic can be alternatives to increase interest in STEM research in Indonesia. The active role of the government and researchers is needed so that the implementation of STEM in Indonesia can be carried out evenly at all levels of education units and all provinces in Indonesia.

\section{SUGGESTIONS}

The data source used in this study is the Google Scholar database, so it is necessary to conduct similar research on other databases such as Scopus, ERIC, or the web of science. 


\section{ACKNOWLEDGEMENT}

Thank you for the suggestions and corrections from the reviewers so that this article becomes worthy of publication.

\section{REFERENCES}

Abdurrahman, A., Nurulsari, N., Maulina, H., \& Ariyani, F. (2019). Design and validation of inquiry-based STEM learning strategy as a powerful alternative solution to facilitate gift students facing 21 st century challenging. Journal for the Education of Gifted Young Scientists, 7(1), 33-56. https://dergipark.org.tr/en/download/article-file/685205

Abidah, A., Hidaayatullaah, H. N., Simamora, R. M., Fehabutar, D., \& Mutakinati, L. (2020). The impact of Covid-19 to Indonesian education and its relation to the philosophy of "Merdeka Belajar." Studies in Philosophy of Science and Education, 1(1), 38-49. https://doi.org/10.46627/sipose.v1i1.9

Adlim, M., Saminan, \& Ariestia, S. (2015). Pengembangan modul STEM terintegrasi kewirausahaan untuk meningkatkan keterampilan proses sains di SMA Negeri 4 Banda Aceh. Jurnal Pendidikan Sains Indonesia, 03(02), 112-121.

Afriana, J., Permanasari, A., \& Fitriani , A. (2016). Project based learning integrated to STEM to enhance elementary school's students scientific literacy. Jurnal Pendidikan IPA Indonesia, 5 (2) (2016) 261-267.

Agustin, M.D, Lesmono, A.D, \& Widodo, H.M. (2020). Model problem based learning (PBL) dengan pendekatan science technology engineering mathematics (STEM) dalam pembelajaran fisika materi eastisitas di kelasXI MIPA 4 SMA Negeri 2 Jember. Jurnal Pembelajaran Fisika, Vol 9 No 2.

Ahied, M., Muharrami, L. K., Fikriyah, A., \& Rosidi, I. (2020). Improving students' scientific literacy through distance learning with augmented reality-based multimedia amid the covid-19 pandemic. Jurnal Pendidikan IPA Indonesia, 9(4), 499-511.

Akhmad, Y., Masrukhi, M., \& Indiatmoko, B. (2020). The effectiveness of the integrated project-based learning model STEM to improve the critical thinking skills of elementary school students. Educational Management, 9(1), 9-16.

Altınpulluk, H., Kesim, M., \& Kurubacak, G. (2020). The usability of augmented reality in open and distance learning systems: A qualitative Delphi study. Open Praxis, 12(2), 283.

Amri, M.S, Sudjimat, D.A, \& Nurhadi, D. (2020). Mengkombinasikan project-based learning dengan STEM untuk meningkatkan hasil belajar teknikal dan karakter kerja siswa SMK. Jurnal Teknologi, Kejuruan, dan Pengajaran, 1(43).

Ananda, P. N., \& Salamah, U. (2021). Meta Analisis Pengaruh Integrasi Pendekatan STEM Dalam Pembelajaran IPA Terhadap Kemampuan Berpikir Kritis Peserta Didik. Jurnal Penelitian Pembelajaran Fisika, 7(1). 
Anwar, C., Sopandi, W., Sa'ud, U. S., \& Pratiwi, W. T. (2020). A portrait of the engineeringoriented natural science lesson plan for teaching and learning in 5th grade elementary school of elementary laboratory UPI Bandung. International Conference on Elementary Education, 2(1), 1635-1641.

Apriliya, S., Sunendar, D., Mulyati, Y., \& Sumiyadi, S. (2019). Holistic and attractive: Children's story book with STEM for elementary school. Journal of Physics: Conference Series, 1318(1), 12071.

Apriyani, R., Ramalis, T., \& Suwarma, I. (2019). Analyzing students' problem solving abilities of direct current electricity in STEM-based learning. Journal of Science Learning, 2(3), $85-91$.

Areba, G. N. (2020). COVID-19 pandemic impact on Kenyan education sector: learner challenges and mitigations. Journal of Research Innovation and Implications in Education, 4(2), 128-139.

Ariesta, Putra, \& Kurniawan. (2015). Carbon monoxide gas detector as integrated chemistry learning media on STEM (Science, Technology, Engineering, and Mathematics). Proceedings of the IConSSE FSM SWCU (2015), BC 41-47.

Arksey, H., \& O’Maley, L. (2005). Scoping studies: towards a methodological framework. International Journal of Social Research Methodology, 8(1), 19-32.

Baihaqi, M. A., Sarwi, S., \& Ellianawati, E. (2020). The implementation of project-based learning with integrated stem in distance learning to improve students' communication skills. Educational Management, 227-233. https://journal.unnes.ac.id/sju/index.php/eduman/article/view/39982

Basuki, D. W., Besari, A. R. A., Agata, D., \& Hasyim, N. S. (2018). Design and Implementation of STEM Learning Module to Enhance Education Learning Outcome for Middle School. Advanced Science Letters, 24(1), 307-309.

Christopoulos, A., Pellas, N., \& Laakso, M. (2020). education sciences A Learning Analytics Theoretical Framework for. Education Science, 10(11), 317.

Dewi, M., Kaniawati, I. \& Suwarma, I. R. (2018). Penerapan pembelajaran fisika menggunakan pendekatan STEM untuk meningkatkan kemampuan memecahkan masalah siswa pada materi listrik dinamis. Seminar Nasional Quantum \#25 (2018) 2477-1511 (5pp).

Devi, N.A.I, Lesmono, A.D, \& Widodo, H.M. (2020). Analisis kreativitas matematis siswa SMA melalui project based learning terintegrasi STEM pada pembelajaran Fisika elastisitas di kelas XI MIPA 6 SMAN 2 Jember. Jurnal Pembelajaran Fisika, 9(3).

Dywan, A. A., \& Airlanda, G. S. (2020). Efektivitas model pembelajaran project based learning berbasis STEM dan tidak berbasis STEM terhadap kemampuan berpikir kritis siswa. Jurnal Basicedu, 4(2), 344-354. http://jbasic.org/index.php/basicedu/article/view/353

Erviana, V. Y., \& Asmara, A. P. (2019). STEM-integrated encyclopaedia as the enrichment for elementary school students. Jurnal Prima Edukasia, 7(2), 114-127. 
Faregh, S. A., \& Sisi, M. J. (2020). Technology of Education Journal The impact of interactive augmented reality based education on the learning and remembering of empirical science lesson. 14(3), 571-582.

Farwati, R., Permanasari, A., Firman, H., \& Suhery, T. (2018). Integration of science, technology, engineering and mathematics: The multidisciplinary approach to enhance the environmental literacy of prospective chemistry teachers. Chemistry: Bulgarian Journal of Science Education, 27(1), 37-51.

Farwati, R., Metafisika, K., Sari, I., Sitinjak, D., Solikha, D. F., \& Putra, E. E. (2021). STEM Education Dukung Merdeka Belajar (dilengkapi dengan Perangkat Pembelajaran Berbasis STEM). CV. DOTPLUS https://books.google.co.id/books?id=TeIhEAAAQBAJ\&hl=id\&sitesec=reviews

Fatimah, S., Hamdu, G., \& Nugraha, A. (2019). Pengembangan lembar kerja siswa pada pembelajaran outdoor berbasis STEM di sekolah dasar. PEDADIDAKTIKA: Jurnal Ilmiah Pendidikan Guru Sekolah Dasar, 6(1), 101-107.

Fauville, G., Queiroz, A. C. M., Hambrick, L., Brown, B. A., \& Bailenson, J. N. (2021). Participatory research on using virtual reality to teach ocean acidification: a study in the marine education community. Environmental Education Research, 27(2), 254-278.

Ferdiansyah, I. (2015). Difference learning outcomes of students using STS approach, SETS, and the STEM learning concept virus. Thesis. not published. Faculty of Science of Tarbiyah and Teaching. State Islamic University Syarif Hidayatullah: Jakarta.

Firdaus, A. R., \& Rahayu, G. D. S. (2019). Effect of STEM-based learning on the cognitive skills improvement. Elementary School Forum (Mimbar Sekolah Dasar), 6(2), 198207.

Franchi, T. (2020). The Impact of the Covid-19 pandemic on current anatomy education and future careers: a student's perspective. Anatomical Sciences Education, 13(3), 312315.

Gandi, A. S. K., Haryani, S., \& Setiawan, D. (2019). The effect of project-based learning integrated STEM toward critical thinking skill. Journal of Primary Education, 8(7), $18-23$.

Georgieva-Tsaneva, G., \& Serbezova, I. (2020). Virtual Reality and Serious Games Using in Distance Learning in Medicine in Bulgaria. International Journal of Emerging Technologies in Learning, 15(19), 223-230.

Hamdu, G., Fuadi, F. N., Yulianto, A., \& Akhirani, Y. S. (2020). The Effectiveness of mobile augmented reality assisted stem-based learning on scientific literacy and students' achievement: items quality analysis using Rasch model to measure elementary school students' critical thinking skill on Stem learning. JPI (Jurnal Pendidikan Indonesia), 9(1), 61-74. 
Hamdu, G., \& Rostiana, N. I. (2020). Desain lembar kerja siswa pada pembelajaran STEM untuk siswa sekolah dasar. Refleksi Edukatika: Jurnal Ilmiah Kependidikan, 11(1), 7987. https://jurnal.umk.ac.id/index.php/RE/article/view/4809

Hani, R. \& Suwarma, I. R. (2018). Profil motivasi belajar IPA siswa sekolah menengah pertama dalam pembelajaran IPA berbasis STEM. Jurnal Wahana Pendidikan Fisika, $3(1), 62-68$.

Hanif, S., Wijaya, A., Winarno, N., \& Salsabila, E. (2019). The use of STEM project-based learning towards students' concept mastery in learning light and optics. Journal of Physics: Conference Series, 1280(032051).

Harfouche, A. L., \& Nakhle, F. (2020). Creating Bioethics Distance Learning Through Virtual Reality. Trends in Biotechnology, 38(11), 1187-1192.

Haryanti, A. \& Suwarma, I. R. (2018). Profil keterampilan komunikasi siswa SMP dalam pembelajaran IPA berbasis STEM. Jurnal Wahana Pendidikan Fisika, 3(1), 49-54.

Hudha, M. N., Batlolona, J. R., \& Wartono, W. (2019). Science literation ability and physics concept understanding in the topic of work and energy with inquiry-STEM. AIP Conference Proceedings, 2202(December). https://doi.org/10.1063/1.5141676.

Ismail, Permanasari, A., \& Setiawan,W. (2016). STEM virtual lab : an alternative practical media to enhance student's scientific literacy. Jurnal Pendidikan IPA Indonesia, 5(2) (2016) 239-246.

Iqbal, M., Latifah, S., \& Irwandani, I. (2019). Pengembangan video blog (Vlog) channel Youtube dengan pendekatan stem sebagai media alternatif pembelajaran daring. Inovasi Pembangunan: Jurnal Kelitbangan, 7(2), 135.

Iyer, P., Aziz, K., \& Ojcius, D. M. (2020). Impact of COVID-19 on dental education in the United States. Journal of Dental Education, 84(6), 718-722.

Izzah, N., Asrizal, A., Festiyed, F. (2021). Meta Analisis Effect Size Pengaruh Bahan Ajar IPA dan Fisika Berbasis STEM terhadap Hasil Belajar Siswa. Jurnal Pendidikan Fisika, 9(1), 114-132.

Kamal, M. I., Zubanova, S., Isaeva, A., \& Movchun, V. (2021). Distance learning impact on the English language teaching during COVID-19. Education and Information Technologies, 0123456789. https://doi.org/10.1007/s10639-021-10588-y

Kapila, V. \& Iskander, M. (2014). Lessons learned from conducting a K12 project to revitalize achievement by using instrumentation in Science Education. Journal of STEM Education, 15 (1), pp. 46-51.

Kemendikbud. (2020). Kemendikbud Selenggarakan KIHAJAR STEM 2020 Wujudkan Generasi Pelajar Pancasila. https://www.kemdikbud.go.id/main/blog/2020/10/kemendikbud-selenggarakankihajar-stem-2020-wujudkan-generasi-pelajar-pancasila 
Kurniasih, Y., Hamdu, G., \& Lidinillah, D. A. M. (2020). Rubrik asesmen kinerja berpikir kritis pada pembelajaran STEM dengan media lightning tamiya car. Jurnal Ilmiah Sekolah Dasar, 4(2), 174-185. https://ejournal.undiksha.ac.id/index.php/JISD/article/view/25172.

Lestari, T. P., Sarwi, \& Sumarti, S. S. (2018). STEM-based project based learning model to increase science process and creative thinking skills of 5thGrade. Journal of Primary Education, 7(1), 18-24.

Liliawati, W., Rusnayati, H., Purwanto, \& Aristantia G. 2018. Implementation of STEAM education to improve mastery concept. The 2nd Annual Applied Science and Engineering Conference (AASEC 2017) IOP Conf. Series: Materials Science and Engineering 288 (2018) 012148.

LPMP Aceh Kemdikbud . (2021). Kolaborasi Dengan Direktorat Sekolah Dasar Kemdikbud Dan Disdikbud Kota Banda Aceh LPMP Provinsi Aceh Selenggarakan Workshop Persiapan Pembelajaran Tatap Muka (Ptm) Melalui Project Based Learning (PBL) STEM. $\quad$ https://www.lpmp-aceh.com/persiapan-sekolah-dalam-melaksanakanpembelajaran-tatap-muka-ptm-melalui-project-based-learning-pbl-stem/

Maula, N. R., \& Fatmawati, L. (2020). Pengembangan media pembelajaran Kayaku (Kayanya Alam Negeriku) berbasis STEM kelas IV sekolah dasar. Jurnal Ilmiah Sekolah Dasar, 4(1), 97-105. https://ejournal.undiksha.ac.id/index.php/JISD/article/view/22351/15413.

Maulidi, A., Lesmono, A. D., \& Supriadi, B. (2019). Inovasi pembelajaran Fisika melalui penerapan model PBL (problem based learning) dengan pendekatan stem education untuk meningkatkan hasil belajar siswa pada materi elastisitas dan hukum Hooke di SMA. Jurnal Seminar Nasional Fisika, 4(1), 185-190.

McDonald, C. V. (2016). STEM Education: A review of the contribution of the disciplines of science, technology, engineering and mathematics. Science Education International, 27(4), 530-569.

McFaul, H., \& FitzGerald, E. (2020). A realist evaluation of student use of a virtual reality smartphone application in undergraduate legal education. British Journal of Educational Technology, 51(2), 572-589.

Mufidah, I. A. (2019). The implementation of science, technology, engineering, and mathematics (STEM) learning to improve basic assking skills and learning achievements students of elementary school. AL-ISHLAH: Jurnal Pendidikan, 11(2), 210-222.

Nambiar, D. (2020). The impact of online learning during COVID-19: students' and teachers' perspective. The International Journal of Indian Psychology, 8(2), 783-793.

Nisa, P., \& Nugroho, O. F. (2020). Pengembangan bahan ajar IPA berbasis STEM pada materi sumber energi di kelas IV SDN Serdang Wetan. Seminar Nasional Ilmu Pendidikan $\begin{array}{llllll}\text { Dan Multi } & \text { Disiplin } & 3 & \text { (SNIPMD } & 3 \text { ), }\end{array}$ https://prosiding.esaunggul.ac.id/index.php/snip/article/view/46. 
Nordin, N. A. A., Majid, N. A. A., \& Zainal, N. F. A. (2020). Mobile augmented reality using $3 \mathrm{~d}$ ruler in a robotic educational module to promote stem learning. Bulletin of Electrical Engineering and Informatics, 9(6), 2499-2506.

Nuraziza, R. \& Suwarma, I. R. 2018. Menggali keterampilan creative Problem Solving yang Dimiliki Siswa SMP Melalui Pembelajaran IPA Berbasis STEM. Jurnal Wahana Pendidikan Fisika, 3(1), 55-61.

Nurlenasari, N., Lidinillah, D. A. M., Nugraha, A., \& Hamdu, G. (2019). Assessing 21st century skills of fourth-grade student in STEM learning. Journal of Physics: Conference Series, 1318(1), 12058.

Permanasari, A. (2016). STEM Education: inovasi dalam pembelajaran sains. Seminar Nasional Pendidikan Sains VI, Surakarta. Diakses kembali pada https://media.neliti.com/media/publications/173124-ID-stem-education-inovasidalam-pembelajara.pdf.

Petrov, P. D., \& Atanasova, T. V. (2020). The Effect of augmented reality on students' learning performance in stem education. Information (Switzerland), 11(4). https://doi.org/10.3390/INFO11040209

Popyk, A. (2021). The impact of distance learning on the social practices of schoolchildren during the COVID-19 pandemic: reconstructing values of migrant children in Poland. European Societies, 23(S1), S530-S544.

PPPPTK\&PLB. (2020). Diklat Daring "STEAM bagi guru TK." https://p4tktkplb.kemdikbud.go.id/index.php/pages/struktur-organisasi/diklat-daringsteam-bagi-guru-tk

Prasadi, A. H., Wiyanto, W., \& Suharini, E. (2020). The Implementation of Student Worksheet Based on STEM (Science, Technology, Engineering, Mathematics) and Local Wisdom to Improve of Critical Thinking Ability of Fourth Grade Students. Journal of Primary Education, 9(3), 227-237.

Priyani, N. E., \& Nawawi, N. (2020). Pembelajaran IPA berbasis Ethno-STEM berbantu mikroskop digital untuk meningkatkan keterampilan proses sains di sekolah perbatasan. WASIS: Jurnal Ilmiah Pendidikan, 1(2), 99-104. https://jurnal.umk.ac.id/index.php/wasis/article/view/5435.

Putri, C. D., Pursitasari, I. D., \& Rubini, B. (2020). Problem Based Learning Terintegrasi STEM Di Era Pandemi Covid-19 Untuk Meningkatkan Keterampilan Berpikir Kritis Siswa. Jurnal IPA \& Pembelajaran IPA, 4(2), 193-204. https://doi.org/10.24815/jipi.v4i2.17859.

Putri, R. S., Purwanto, A., Pramono, R., Asbari, M., Wijayanti, L. M., \& Hyun, C. C. (2020). Impact of the COVID-19 pandemic on online home learning: An explorative study of primary schools in Indonesia. International Journal of Advanced Science and Technology, 29(5), 4809-4818. 
Pujiasih, E.(2020).Membangun Generasi Emas dengan Variasi Pembelajaran Online di Masa Pandemi Covid-19.Jurnal Karya Ilmiah GuruVol. 5, No.1 Edisi Khusus KBM Pandemi COVID-19.

P4TKIPA Kemdikbud. (2018). Diklat Integrasi STEM dalam Implementasi Kurikulum 2013. https://p4tkipa.kemdikbud.go.id/berita/detail/diklat-integrasi-stem-dalamimplementasi-kurikulum-2013

Rahmat, A. A., Hamdu, G., \& Nur'aeni, E. (2020). Pengembangan Soal Tes Tertulis Berbasis STEM Dengan Pemodelan Rasch Di Sekolah Dasar. Metodik Didaktik: Jurnal Pendidikan Ke-SD-An, 16(1). https://ejournal.upi.edu/index.php/MetodikDidaktik/article/view/25099.

Rahmawati, Y., Agustin, M., Ridwan, A., Erdawati, E., Darwis, D., \& Rafiuddin, R. (2019). The development of chemistry students' 21 century skills through a STEAM project on electrolyte and non-electrolyte solutions. Journal of Physics : Conference Series. 1402(055049). doi:10.1088/1742-6596/1402/5/055049

Rahmiza, S., Adlim, \& Mursal. (2015). Pengembangan LKS STEM (Science, Technology, Engineering, and Mathematics) dalam meningkatkan motivasi dan aktivitas belajar siswa SMA Negeri 1 Beutong pada materi induksi elektromagnetik. Jurnal Pendidikan Sains Indonesia, 03(01), 239-250.

Ridlo, S., \& others. (2020). Critical Thinking Skills Reviewed from Communication Skills of the Primary School Students in STEM-Based Project-Based Learning Model. Journal of Primary Education, 9(3), 311-320. https://journal.unnes.ac.id/sju/index.php/jpe/article/view/27573/16749.

Rizun, M., \& Strzelecki, A. (2020). Students' acceptance of the covid-19 impact on shifting higher education to distance learning in Poland. International Journal of Environmental Research and Public Health, 17(18), 1-19.

Rochman, C., Nasudin, D., \& Rokayah, R. (2019). Science literacy on science technology engineering and math (STEM) learning in elementary schools. Journal of Physics: Conference Series, 1318(1), 12050. https://iopscience.iop.org/article/10.1088/17426596/1318/1/012050/meta.

Rosidin, U., Suyatna, A., \& Abdurrahman, A. (2019). A combined HOTS-based assessment/STEM learning model to improve secondary students' thinking skills: A development and evaluation study. Journal for the Education of Gifted Young Scientists, 7(3), 435-448. https://doi.org/10.17478/jegys.518464.

Sakinah, K., Triwoelandari, R., \& Fahri, M. (2020). Development of Ispring Learning Media to Improve Student's Curiosity Character in STEM-Based Science Learning/Pengembangan Media Pembelajaran Ispring untuk Meningkatkan Karakter Rasa Ingin Tahu Siswa Pada Pembelajaran IPA Berbasis STEM. Al-Mudarris: Journal Of Education, 3(2), 118-131. https://e-journal.staima-alhikam.ac.id/index.php/almudarris/article/view/499. 
Sagala, R., Umam, R., Thahir, A., Saregar, A., \& Wardani, I. (2019). The effectiveness of stembased on gender differences: The impact of physics concept understanding. European Journal of Educational Research, 8(3), 753-761. https://doi.org/10.12973/eujer.8.3.753.

Sampurno, Sari \& Wijaya. (2015). Integrating STEM (Science, Technology, Engineering, and Mathematics) and Disaster (STEM-D) education for building students' disaster literacy. International Journal of Learning and Teaching, 1(1), 73-76

Santosa, T. A., Razak, A., Lufri, L., Zulyusri, Z., Fradila, E., \& Arsih, F. . (2021). MetaAnalisis: Pengaruh Bahan Ajar Berbasis Pendekatan STEM Pada Pembelajaran Ekologi . Journal of Digital Learning and Education, 1(01), 1-9. https://doi.org/10.52562/jdle.v1i01.24

Saputra, R. A., Herpratiwi, H., Caswita, C., \& Others. (2020). Developing a STEM-based students' worksheet building material in elementary school Bandar Lampung City. Jurnal Prima Edukasia, 8(2), 145-155.

Sari, I., Sinaga, P., Hernani, H., \& Solfarina, S. (2020). Chemistry Learning via Distance Learning during the Covid-19 Pandemic. Tadris: Jurnal Keguruan Dan Ilmu Tarbiyah, 5(1), 155-165. https://doi.org/10.24042/tadris.v5i1.6346

Septine, N. V., Wijayanti, O., \& Badarudin, B. (2019). Peningkatan sikap ilmiah dan prestasi belajar menggunakan model Science, Technology, Engineering, and Mathematics di kelas V MIM kramat. Premiere Educandum: Jurnal Pendidikan Dasar Dan Pembelajaran, 9(2), 91-99. http://ejournal.unipma.ac.id/index.php/PE/article/view/4470/pdf.

Setiawaty, S., Imanda, R., Fitriani, H., \& Sari, R. P. (2020). Pengembangan LKS sains berbasis STEM untuk siswa Sekolah Dasar. Seminar Nasional Peningkatan Mutu Pendidikan, l(1).

Siregar, Y. E. Y., Rachmadtullah, R., Pohan, N., Zulela, M. S., \& others. (2019). The impacts of science, technology, engineering, and mathematics (STEM) on critical thinking in elementary school. Journal of Physics: Conference Series, 1175(1), 12156.

Sugiarti, A. C., Suyatno, S., \& Sanjaya, I. G. M. 2018. The development of learning material using learning cycle 5E model based stem to improve students' learning outcomes in Thermochemistry. International Conference on Science Education (ICoSEd) IOP Conf. Series: Journal of Physics: Conf. Series 1006 (2018) 012039.

Sukendra, I.K, Surat, I.M, Darmada, I.M, \& Fridayanthie, P.D. (2020).Program Kemitraan Masyarakat Pembuatan Rencana Pelaksanaan Pembelajaran Dengan Pendekatan STEM Berorientasi pada Soal HOTS. JASINTEK, Vol.2 No.1, 23-31.

Sumarwa, I. R., Astuti, P., \& Endah, E. N. (2015). "Balloon powered car" sebagai media pembelajaran IPA berbasis STEM (science, technology, engineering, and mathematics) . Prosiding Simposium Nasional Inovasi dan Pembelajaran Sains 2015 (SNIPS 2015) (pp. 373-376). Bandung: Universitas Pendidikan Indonesia. 
Supriyati,Yetti, Permana,H.A, \& Aziz, N.D.S.(2020).Bahan Ajar Elektronik Berbasis STEM untuk Blended Learning pada Materi Fluida SMA. Prosiding Seminar Nasional Fisika (E-Journal) SNF 2020 Volume IX.

Sutoyo, S., Azizah, U., \& Alamin, S. 2019. Effectiveness of the guided inquiry model integrated with STEM to improve the student critical thinking skills in chemistry learning. International Journal of Innovative Science and Research Technology, 4(12).

Syadiah, A. N., \& Hamdu, G. (2020). Analisis rasch untuk soal tes berpikir kritis pada pembelajaran STEM di sekolah dasar. Premiere Educandum: Jurnal Pendidikan Dasar Dan Pembelajaran, 10(2), 138-148.

Toip, S. A., Hamdu, G., \& Elan, E. (2018). Pengembangan Multimedia Interaktif Pelaksanaan Pembelajaran Outdoor Tema Daerah Tempat Tinggalku Berbasis STEM di SD. PEDADIDAKTIKA: Jurnal Ilmiah Pendidikan Guru Sekolah Dasar, 5(4), 111-120.

Twiningsih, A. T. (2020). Improving Learning Outcomes Through the Use of Media STEM Based in Volcano Eruption Simulation in the Theme of Natural Events. International Journal of Theory and Application in Elementary and Secondary School Education, 2(2), 64-78.

Utomo, A. P., Rosalina,A. M., Wahono, B., \& Narulita, E. 2018. Developing Students' Book Based on STEM (Science Technology Engineering and Mathematics) Approach on Biotechnology Topics of Grade XII. Journal of Education and Learning (EduLearn), 12(3).

Wahyu, Y., Suastra, I. W., Sadia, I. W., \& Suarni, N. K. (2020). The Effectiveness of Mobile Augmented Reality Assisted Stem-Based Learning on Scientific Literacy and Students' Achievement. International Journal of Instruction, 13(3), 343-356.

Widiarti, H.R, Rokhim, D.A, \& Syafruddin, A.B. (2020). The Development of Electrolysis Cell Teaching Material Based on STEM-PjBL Approach Assisted by Learning Video: A Need Analysis. Jurnal Pendidikan IPA Indonesia .9(3) 309-318.

Wisudawati, A. W. 2018. Science Technology Engineering and Mathematics (STEM) Education Approach against a Microscopic Representation Skill in Atom and Molecule Concept. International Journal of Chemistry Education Research International Journal of Chemistry Education Research, 2(1), 1-5.

Yildirim, B., Sahin Topalcengiz, E., Arikan, G., \& Timur, S. (2020). Using Virtual Reality in the Classroom: Reflections of STEM Teachers on the Use of Teaching and Learning Tools. Journal of Education in Science, Environment and Health, 6(3), 231-245. https://doi.org/10.21891/jeseh.711779

Yuanita, Y., \& Kurnia, F. (2019). Pengembangan Bahan Ajar Berbasis STEM (Science, Technology, Engineering, and Mathematics) Materi Kelistrikan untuk Sekolah Dasar. Profesi Pendidikan Dasar, 6(2), 199-210. 